\title{
Determination of Degrees of Oxidative Stress and Some Antioxidant Enzyme Activities in Basketball Players
}

\author{
Mustafa BİLICI ${ }^{1}$, Mustafa ATLI ${ }^{* 2}$ \\ ${ }^{I}$ Division of Biochemistry, Department of Chemistry, Faculty of Science, Van Yuzuncu Yil University \\ ${ }^{2}$ Department of Physical Education and Sports, Bitlis Eren University \\ (ORCID:0000-0002-8689-6463) (ORCID: 0000-0002-3868-4570)
}

\begin{abstract}
Objective: It is known that phsical activity is an important factor in prevention and treatments of heart diseases. It has been reported that acute exercise is a major source of free radicals formation of oxidative stress. In this study, determination of degrees of oxidative stress and some antioxidant enzyme activities in basketball players haves been aimed. Method: In this study, 14 male sportsmen who play basketball and 14 sedantery individuals have been taken into the study. The degrees of malondialdehyde (MDA) and catalase(CAT) activities and reduced glutathione(GSH) have been measured as spectrophotometric. Conclusion: Statistically significant difference between degrees of MDA, CAT and GSH of control group and basketball players has been found(p<0.05). A significant decrease in values of MDA and catalase, which is an important antioxidant enzyme activity, has come up in basketball players compared to control group, value of GSH in basketball players has been found higher than that of control group ( $\mathrm{p}<0.05)$. Consequently, in sportsmen who take part in basketball team, an increase in GSH has been seen whereas a decrease in Catalase and MDA has occured. It can be said that reduced glutathione which has the characteristic of antioxidant enzyme is a good protector against oxidative damage in individuals who do intensive exercise. Moreover, oxidative stress can affect the etiopathogenesis of many diseases.
\end{abstract}

Anahtar kelimeler: Basketbol, Katalaz, Malondialdehit, Glutatyon, Oksidatif stres

\section{Basketbol oyuncularında oksidatif stres düzeyi ve bazı antioksidant enzim aktivitelerin saptanması}

\begin{abstract}
$\ddot{\mathbf{O z}}$
Amaç: Fiziksel aktivitenin kalp hastalıklarının tedavi ve önlenmesinde önemli bir faktör olduğu bilinmektedir. Akut egzersizin, oksidatif strese bağlı serbet radikal oluşumunda büyük bir kaynak olduğu rapor edilmektedir $\mathrm{Bu}$ çalışmada basketbol oyuncularında, oksidatif stres düzeyi ve bazı antioksidant enzim aktivite düzeylerinin saptanması amaçlanmıştır. Metot: Çalışmamızda, Çalışmaya, 14 aktif erkek basketbolcu ve 14 sedanter birey dahil edildi. Çalışmaya katılan bireylerin, yağ asitlerinin, serbest radikallerle reaksiyonu sonucu oluşan peroksidasyon ürünlerinden, malondialdehit (MDA), katalaz (CAT) aktivitesi ve Redükte glutatyon (GSH) düzeyleri spektrofotometrik olarak ölçülmüştür. Sonuçlar: Basketbol grubu ile kontrol grubunun, MDA, CAT ve GSH düzeyleri arasında istatistiksel olarak anlamlı fark bulunmuştur ( $\mathrm{p}<0.05)$. Önemli bir antioksidant enzim aktivitesi olan Katalaz ve MDA değerlerinde basketbolcularda kontrol grubuna göre önemli bir azalma meydana gelirken, aktif olarak oynayan basketbolcularda GSH değeri kontrole grubundan daha yüksek bulunmuştur $(\mathrm{p}<0.05)$. Sonuç olarak, basketbol takımında yer alan ve aktif olarak basketbol oynayan sporcularda, Katalaz ve MDA da azalma görülürken, GSH da ise artış bulunmuştur. Çok güçlü bir antioksidant enzim olan katalaz enzim aktivitesinin yoğun egzersiz yapan bireylerde oksidatif hasara karşı iyi bir koruyucu olduğu söylenebilir.
\end{abstract}

Keywords: Basketball, Catalase, Glutathione Malondialdehyde, Oxidative Stress

\footnotetext{
*Sorumlu yazar: matli@beu.edu.tr

Geliş Tarihi: 05.11.2019, Kabul Tarihi: 27.11.2019
} 


\section{Introduction}

Oxidative stress is defined as an increase of reactive oxygen species as a result of deterioration between oxidant and anti-oxidant balance in body [1,2]. Free oxygen radicals (free radicals) form most of reactive oxygen species. Unstable free radicals change structures of other molecules by reacting with them [3]. Free radicals are physiologic products of aerobic metabolism and are formed continually. Free radicals have important role pathologies of such diseases as atherosclerosis, cancer, inflammation, neurodegenerative. The increase in muscle contractions during exercise enhances metabolic activity. Consequently, there is an increase in the formation of such free radicals as superoxide, hydrogen peroxide and hydroxide radical. Consisted free radicals corrode lipids, proteins and DNA [4]. It has been determined that free radicals increase during physical activity and exercise [5].

Being reason for oxidative stress, exercise may create imbalance between antioxidant and ROS[6]. The formation of free radical changes according to the type, the severity and the time of exercise. Amount of consumed oxygen and rate of mechanic damage consisted on tissues are the factors contributing to the formation of free radical. Antioxidant defense system stops to work against free radicals consisted during exercise and tries to protect the body from possible damages [7].

Catalase removes hydrogen peroxide by turning it into water and oxygen, which plays and important role in abatement of oxidative stress $[8,9]$. Malondialdehyde (MDA) is often used as indicator of oxidative stress in determination of lipid peroxidation. MDA leads to damage cell membrane by reacting with vicinal fatty acids [10]. Glutathione protects tissues from oxidative damage during exercise. Also, Glutathione protects erythrocytes, leucocytes and eye-lenses from oxidative stress [6, 10-15]. In this study, determination of oxidative stress degree and some antioxidant enzyme activities in basketball players has been aimed.

\section{Material and Method}

In this study, 14 sedantery students and 14 healthy volunteer students, who plays in basketball team of Van Yuzuncu Yil University, were used as subjects. Blood samples were taken from sportsmen and sedanteries, and then, their serums were separated in Biochemistry laboratory of Faculty of Science at our university. Then, levels of malondialdehyde(MDA), catalase(CAT) enzyme activity and reduced glutathione(GSH) were determined spectrophotometricly in Biochemistry laboratory of Department of Chemistry, Faculty of Science at Van Yuzuncu Yil University.

\section{Determination of Malondialdehyde (MDA) level}

Being one of peroxidation products which are formed as a result of reaction of fatty acids with free radicals, malondialdehyde has been measured spectrophotometricly in consequence of its getting into colorful form with thiobarbutiric acid[16].

\section{Determination of Reduced Glutathione (GSH)}

Reduced glutathione(GSH) has been measured through formation of yellow colour as result of the reaction of sulfhydryl groups, found in erythrocyte, with DTNB 5',5'-(2-dithiobis nitro benzoic acid). $800 \mu$ of phosphate buffer was added to $200 \mu 1$ of serum. Initial absorbance (OD1) was recorded at 412 $\mathrm{nm}$, then, $100 \mu$ l of Ellman's reagent was added to the same example, and second absorbance (OD2) was recorded. Measurement of reduced glutathione level in the blood serum has been made at $412 \mathrm{~nm}$ on spectrophotometer in 24 hours [17].

\section{Determination of Catalase (CAT) Activity}

In this study, in which hydrogen peroxide was used as substrate, catalase activity was determined according to Aeibi method. Firstly, two tubes were taken. $30 \mathrm{mM}-\mathrm{H}_{2} \mathrm{O}_{2}$ was added to the blind tube in the amount of $1.4 \mathrm{ml}$ and then, over it phosphate buffer was added in the amount of $0.1 \mathrm{ml}$. To the sample tube, $30 \mathrm{mM}-\mathrm{H}_{2} \mathrm{O}_{2}$ was added in the amount of $1.4 \mathrm{ml}$. Enzyme was added over it in the amount of 0.1 $\mathrm{ml}$ and it was mixed with vortex. Absorbances were read twice at $240 \mathrm{~nm}$ at intervals of 30 seconds. So, 
the activity was determined [18].

\section{Statistical Analysis}

In this study, descriptive statistics were expressed as Average, Standard Deviation, and Minimum and Maximum value. Student $t$ test was used in comparison of the groups. Level of statistically significance was taken as $5 \%$ in calculations and SPSS statistical package program was used for calculations.

\section{Results}

In the study, results of comparison of individuals playing basketball with control group have been given in table 1 and figure 1, 2 and 3. Accordingly, for each three feature, differences of individuals playing basketball from control groups have been found statistically significant $(\mathrm{p}<0.05)$. In terms of Catalase and MDA, whereas an important decrease has occurred in individuals playing basketball in terms of values of Catalase and MDA, value of GSH has increased in individuals who play basketball compared to control group. In other words, in basketball players, while Catalase and MDA has decreased, GSH has shown an increase.

Table 1. Descriptive statistics according to groups and results of comparisons.

\begin{tabular}{|c|c|c|c|c|c|c|c|c|}
\hline & & $\mathbf{N}$ & Mean & Std. De & Std. Er & r Min & Max & $\mathbf{P}$ \\
\hline \multirow{3}{*}{$\begin{array}{l}\text { Catalase } \\
(\mathbf{E U} / \mathbf{m L})\end{array}$} & Control & 14 & ,0071 & ,0005 & ,0001 &, 0053 & ,0073 & \multirow{2}{*}{0,010} \\
\hline & Sport & 14 &, 0000 & 0000 & 0000 & ,0000 &, 0000 & \\
\hline & General & 28 & 0035 & 0036 & 0006 &, 0000 & 0073 & \\
\hline \multirow{3}{*}{ MDA $(\mu \mathrm{mol} / \mathrm{L})$} & Control & 14 & 16,9722 & 2,5311 & ,6764 & 12,376 & 21,0139 & \multirow{3}{*}{\begin{tabular}{l|l}
$\frac{9}{8}$ & 0,015 \\
8 &
\end{tabular}} \\
\hline & Sport & 14 & 13,8098 & 33,7607 & 1,0051 & 10,454 & 24,7938 & \\
\hline & General & 28 & 15,3910 & 3,5337 & 6678 & 10,454 & 724,7938 & \\
\hline \multirow{3}{*}{$\begin{array}{l}\text { GSH } \\
(\mathbf{m m o l} / \mathrm{gHb})\end{array}$} & Control & 14 & ,01992 &, 0063 & 0016 &, 0110 &, 0320 & \multirow{2}{*}{0,010} \\
\hline & Sport & 14 &, 2680 &, 1215 & 0324 &, 0127 & 4333 & \\
\hline & General & 28 & 1440 &, 1519 & 0287 & ,0110 & ,4333 & \\
\hline
\end{tabular}

$\mathrm{p}<0.05$; shows significant difference between groups

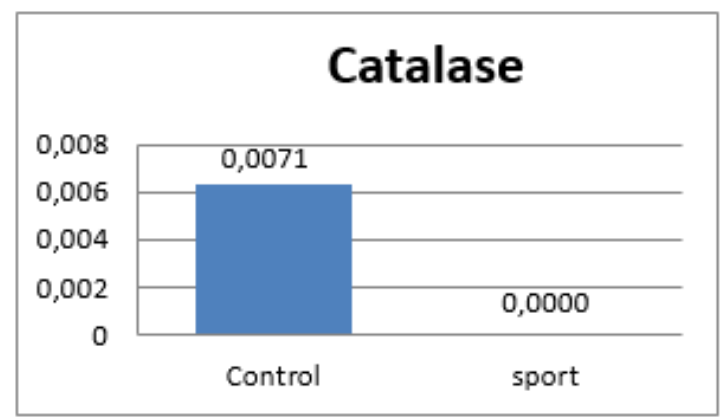

Figure 1. Catalase (CAT) Basketball

Value of CAT has been found low in basketball players compared to control group $(\mathrm{p}<0.05)$. 


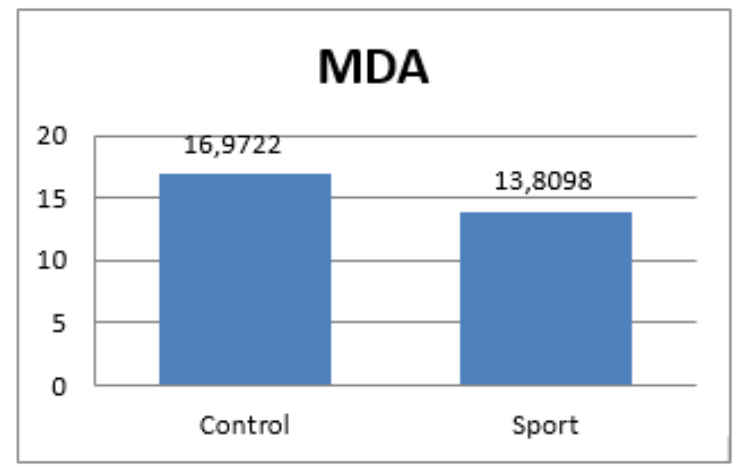

Figure 2. Malondialdehyde(MDA) Basketball

The value of MDA has been found low and significant in basketball players compared to control group $(\mathrm{p}<0.05)$.

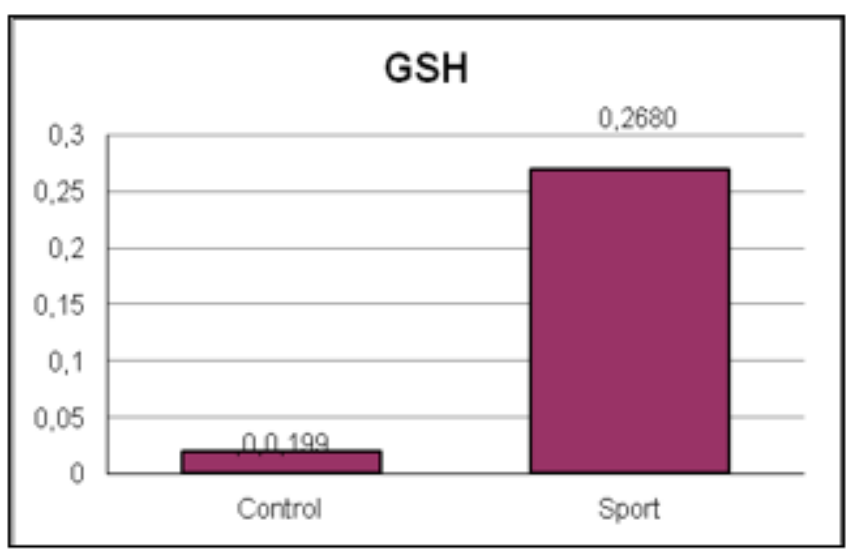

Figure 3. Reduced Glutathione (GSH) Basketball

Value of GSH has been found high and significant in basketball players compared to control group $(\mathrm{p}<0.05)$.

\section{Discussion}

Reactive oxygen species (ROS) are physiologic products of aerobic metabolism. They contribute to regulation of antioxidative processes [20]. Regular physical activity is shown as an important factor in treatment and prevention of cardiovascular disease [19]. Malondialdehyde (MDA) is the last product of lipid peroxidation and is usually used as oxidative stress reagent in determination of lipid peroxidation. MDA leads to various damages on cell membrane by combining with fatty acids $[10,21]$. In some literature studies, it has been found that MDA level rises in some diseases; on the contrary, it decreases in healthy individuals [22-24]. In another study, it has been found that while MDA levels are high in patient groups in the study on ovary cancer, they has been found low in healthy individuals [25]. In our study, a significant decline in MDA levels has been seen in basketball players compared to control group $(\mathrm{p}<0.05)$. It is important that MDA level is low in healthy individuals, especially those who do exercise; because oxidative stress has decreased in blood serums of those who do exercise. This situation affects metabolism positively and may prevent or stop any possible disease that can develop in body.

Catalase is an enzyme which detracts $\mathrm{H}_{2} \mathrm{O}_{2}$ from inside of an oxygen molecule and a water molecule and which is important for antioxidant protecting reactive oxygen radical against this process by means of elimination. Antioxidant systems protects all cells against free radical damage in livings $[26,27]$. Catalase enzyme has been found solvable in erythrocyte[28]. Catalase is an enzyme that can be used for removing hydrogen peroxide, used as oxidizing or bleaching or for the purpose of sterilization, and that can be widely and analytical purposefully used as compound of hydrogen peroxide or glucose biosensors [29]. In another study, catalase enzyme activity has been found significantly low in temporomandibular disorders compared to healthy control individuals [23]. The degree of PON-1, which is an important antioxidant enzyme in Alzheimer patients, has been found low in patients whereas 
it has been high in healthy control individuals [30]. In another study, catalase enzyme activity has been found low in patient groups, on the contrary, it has been found high in healthy individuals in the study on ovary cancer [25]. In literature studies, Bulduk [21] have found CAT level low in both sportsmen and control group in the studies that they did. In those studies, a significant decline has been seen in catalase enzyme activity in individuals who play basketball compared to control group $(\mathrm{p}<0.05)$. Available findings can be said to be in concordance with literature data.

In the studies, it has been determined that reduced glutathione is a good protective in those who do intensive exercise against oxidative damage. Moreover, reduced glutathione protects erythrocytes, leucocytes and eye-lenses against oxidative stress [6, 10-15]. In some other studies, it has been found that reduced glutathione level decreases in some diseases and increases in healthy individuals [22-24]. In another study, it has been found that while reduced glutathione level is low in patient groups in the study on ovary cancer, it has been found high in healthy individuals [11]. As Bulduk [21] expressed, there are different results contradicting with each other according to their features in the studies on effects of antioxidant enzymes based on exercise. In this study, GSH level has risen in the individuals who play basketball compared to control $(\mathrm{p}<0.05)$.

\section{Conclusion}

Consequently, glutathione which has antioxidant enzyme feature can be said to be a good protective in individuals who do intensive exercise against oxidative damage. Oxidative stress can affect the etiopathogenesis of many diseases. Also, adequate exercise may reduce the degree of oxidative stress. Therefore, researches on oxidative stress should be carried out.

\section{References}

[1] Sies H. 1997. Oxidative stress: oxidants and antioxidants. Exp Physiol., 82: 292-295.

[2] Atli M. 2013. Serum paraoxonase activity and lipid hydroperoxide levels in adult football players after three days football tournament. African Health Sciences, 13 (3).

[3] Ersoy G., Hasbay A. 1998. Egzersize bağlı serbest radikal oluşumu ve serbest radikal temizleyicisi besin ögeleri. Spor ve Tip, 6: 11-12.

[4] Radak Z., Chung H.Y., Goto S. 2008. Systemic adaptation to oxidative challenge induced by regular exercise. Free Radic Biol Med., 44 (2): 153-159.

[5] Aslan R., Şekeroğlu M.R. 1996. Egzersize bağlı lipid peroksidasyonu ve antioksidan statüsü çalışmalarında sonuçlara etkili faktörler. Turkish Journal of Sports Medicine, 31: 145-152.

[6] Urso M.L., Clarkson P.M. 2003. Oxidative stress, exercise, and antioxidant supplementation. Toxicology, 189 (1-2): 41-54.

[7] Wellman K.F., Bloomer R.J. 2009. Acute exercise and oxidative stress: a 30 year history. Dynamic Medicine, 8 (1): 1-25.

[8] Memişoğulları R. 2005. Diyabette serbest radikallerin rolü ve antioksidanların etkisi. Düzce Medical Journal, 3: 30-39.

[9] Sureda A., Tauler P., Aguiló A., Cases N., Fuentespina E., Córdova A., Tur J.A., Pons A. 2005. Relation between oxidative stress markers and antioxidant endogenous defences during exhaustive exercise. Free Radic Res., 39 (12): 1317-1324.

[10] Sachdev S., Davies K.J. 2008. Production, detection, and adaptive responses to free radicals in exercise. Free Radic Biol Med., 44 (2): 215-223.

[11] Akkuş İ. 1995. Serbest Radikaller ve Fizyopatolojik Etkileri (Free Radicals and Their Physiopathologic Effects). 1. Baskı, Konya, Mimoza Basım-Yayım ve Dağıtım A.Ş, a. 49-50.

[12] Clarkson P.M., Thompson H.S. 2000. Antioxidants: what role do they play in physical activity and health. Am J Clin Nutr.,72 (2 Suppl): 637S-646S.

[13] Clarkson P.M. 1995. Antioxidants and physical performance. Crit Rev Food Sci Nutr., 35: 131141.

[14] Banerjee A.K., Mandal A., Chanda D., Chakraborti S. 2003. Oxidant, antioxidant and physical exercise. Mol Cell Biochem., 253 (1-2): 307-312.

[15] Valko M., Rhodes C.J., Moncol J., Izakovic M., Mazur M. 2006. Free radicals, metals and antioxidants in oxidative stress-induced cancer. Chem Biol Interact., 160 (1): 1-40. 
[16] Gutteridge J.M. 1995. Lipit peroxidation and antioxidants as biomarkers of tissue damage. Clin. Chem., 41 (12): 1819-1828.

[17] Beutler E., Duron O., Kelly B.M. 1963. Improved method for the determination of blood glutathione. J Lab Clin Med., 61: 882-888.

[18] Aebi H. 1984. Catalase. In: Methots In Enzymology, (Ed: Packer L.), Academic Pres, Orlando 105: 121-126.

[19] Pani G, Colavitti R, Bedogni B, Anzevino R., Borrello S., Galeotti T. 2000. A redox signaling mechanism for density-dependent inhibition of cell growth. J Biol Chem., 275: 38891-38899.

[20] Hambrecht R., Wolf A., Gielen S., Linke A., Hofer J., Erbs S., Schoene N., Schuler G. 2000. Effect of exercise on coronary endothelial function in patients with coronary artery disease. $\mathrm{N}$ Engl J Med., 342: 454-460.

[21] Bulduk E.Ö. 2010. Bayan sporcularda 20 metre mekik koşu testinin oksidatif stres ve antioksidan düzeyleri üzerine etkisinin incelenmesi. Selçuk Üniversitesi, Sağlık Bilimleri Enstitüsü, Doktora Tezi.

[22] Asker S., Asker M., Sarikaya E., Sunnetcioglu A., Aslan M., Demir H. 2015. Oxidative stress parameters and their correlation with clinical, metabolic and polysomnographic parameters in severe obstructive sleep apnea syndrome. Int J Clin Exp Med., , 8 (7): 11449-11455.

[23] Demir C.Y., Koçak O.F., Bozan N., Ersoz M.E., Demir H. 2017. Is There a Role for Oxidative Stress in Temporomandibular Joint Disorders. J Oral Maxillofac Surg. Epub ahead of print.21. pii: S0278-2391 (17): 31422-2.

[24] Radak Z., Chung H.Y., Goto S. 2008. Systemic adaptation to oxidative challenge induced by regular exercise. Free Radic Biol Med., 44 (2): 153-159.

[25] Bilici M., Cim N., Demir H., 2014. Pre and post-operative oxidative stress level in cases with ovarian cancer neoplasia. Medical Science and Discovery, 1(4): 115-117.

[26] Alvying A., Carson P., Flanagan C.L., Ickes C. 1956. Enzymatic deficiency in primaquinsensitive erythrocytes. Science, 14 (124): 484-485.

[27] Holmes R.S, Masters C.J. 1972. Species specific feature of the distribution and multiplicity of mammalian liver catalases. Arch.Biochem. Biophys., 148:217-233.

[28] Percy M.E. 1984. Catalase an old enzyme with a new role. Can. J. Biochem. Cell Biol., 62: 10061014.

[29] Alptekin Ö., Yıldırım D., Özyılmaz G., Tokel S. 2004. Florosile immobilize edilmiş katalaz enziminin immobilizasyon koşullarının optimizasyonu. XVIII. National Chemistry Congree, BK, p. 498, Kars.

[30] Arslan A., Tüzün F.A., Arslan H., Demir H., Tamer S., Demir C., Tasin M. 2016. The relationship between serum paraoxonase levels and carotid atherosclerotic plaque formation in Alzheimer's patients. Neurol Neurochir Pol., 50 (6): 403-409. 